\title{
A Current View of Care of High Risk Pregnancy
}

\section{Yüksek Riskli Gebeliklerin Bakımına Güncel Bir Bakış}

\author{
(i) Büşra YILMAZ, iD Ümran OSKAY
}

İstanbul University-Cerrahpaşa Florence Nightingale Faculty of Nursing, Women’s Health and Disease Nursing, İstanbul, Turkey

\begin{abstract}
Although the pregnancy is planned to go smoothly, it brings with it a number of risks. Pregnancy risks are grouped as low risk, moderate risk and high risk. Every pregnant woman is at risk after pregnancy, even if it is low. Pregnancies which have the conditions that may endanger the life of the mother/baby, $t$ occurring prior to pregnancy orduring pregnancy are defined as high risk pregnancy. Individualized care is very important in the care of high-risk pregnancies. Early diagnosis of high-risk pregnancies is useful in preventing further serious complications that may occur in the future. Pregnant women may also need to be hospitalized for the care and treatment processes of high-risk pregnancies. However, this situation brings with it many disadvantages for the pregnant woman. Problems related to patient safety also arise during hospitalizations. Falls in high-risk pregnancies have an important role in patient safety. The widespread use of mobile applications available at home has contributed to the participation of high-risk pregnant women in the care process, reducing hospitalizations, length of hospital stay and health care needs. These include the treatment of high-risk pregnant women in hospital, coordination of the health care team, providing patient safety, providing health education, providing psychosocial support to the pregnant and her family, and using mobile applications that can be used in the care of pregnant women at home. It is a unique opportunity for nurses to protect, promote and improve the health of pregnant women and their infants. The aim of this review is to provide an up-to-date overview of the care of high-risk pregnancies.
\end{abstract}

Keywords: Risk, pregnancy, care

\section{ÖZ}

Gebelik süreci, sorunsuz geçmesi planlanmasına rağmen beraberinde bir takım riskleri getirir. Gebelik riskleri düşük riskli, riskli ve yüksek riskli olarak gruplandırılır. Her gebe, gebeliği kesinleştikten sonra düşük de olsa risk altındadır. Sıkı takip ve izlemle riskli gebeliklerde, sağlıklı bir şekilde gebeliğin sürdürülmesi hedeflenir. Gebelik öncesinde oluşan veya gebelikle birlikte ortaya çıan annenin/bebeğin yaşamını tehlikeye sokabilecek durumlara sahip olan gebelikler yüksek riskli gebelik olarak ifade edilir. Yüksek riskli gebeliklerin bakımında bireyselleştirilmiş bakım oldukça önemlidir. Yüksek riskli gebeliklerin erken dönemde tanılanması, ilerideki süreçte oluşabilecek daha ciddi komplikasyonların önlenmesinde yararlıdır. Yüksek riskli gebeliklerin bakım ve tedavisinde gebenin hastaneye yatması da gerekebilir. Fakat bu durum gebe için birçok olumsuzluğu beraberinde getirir. Hastaneye yatışlarda hasta güvenliği ile ilgili sorunlar da ortaya çıkmaktadır. Yüksek riskli gebeliklerin hastaneye yatışında düşmeler hasta güvenliği konusunda önemli bir yere sahiptir. Son dönemlerde evde yararlanılabilen mobil uygulamaların kullanımının yaygınlaşması, yüksek riskli gebelerin bakım sürecine katılmasına, hastaneye yatışların, hastanede kalma sürelerinin ve sağlık bakım gereksinimlerinin azalmasına katkı sağlamıştır. Hastanede yatan yüksek riskli gebenin tedavisi, sağlık ekibinin koordinasyonu, hasta güvenliğinin sağlanması, sağlık eğitimi verilmesi, gebe ve ailesine psikososyal destek sağlanması ve evde bakımı sağlanacak gebelerin bakımında yararlanılabilecek mobil uygulamaların kullanılması bu roller arasındadır. Hemşirelere, gebe ve bebeğinin sağlığının korunması, geliştirilmesi ve iyileştirmesi konusunda eşsiz bir firsat sağlar. Bu literatür incelemesinin amacı yüksek riskli gebeliklerin bakımına güncel bir bakışs sunmaktır.

Anahtar Sözcükler: Riskli, gebelik, bakım
Address for Correspondence: Büşra YILMAZ, İstanbul University-Cerrahpaşa Florence Nightingale Faculty of Nursing, Women's Health and Disease Nursing, istanbul, Turkey E-mail:ylmzbsr678@gmail.com ORCID ID: orcid.org/0000-0001-6937-5351
Received: 21.10 .2019

Accepted: 18.02 .2020

Cite this article as: Yılmaz B, Oskay Ü. A Current View of Care of High Risk Pregnancy. Bezmialem Science 2021;9(1):112-9. 


\section{Introduction}

Although it is aimed to have a non-problematic pregnancy, delivery and postpartum period, all pregnant women are in danger for a risky pregnancy. An actual or potential danger to the health/well-being of the mother and fetus and an unexpected medical or obstetric condition related to pregnancy is considered a high risk pregnancy (1). Worldwide, 20 million women have high-risk pregnancies, and more than 800 women die daily from perinatal causes. Of these losses, $6-33 \%$ are in the high risk pregnancy group. Worldwide, $5-10 \%$ of all pregnancies are complicated by preeclampsia. Malaria, tuberculosis and chronic iron deficiency anemia are among the other most common pregnancy complications (2). Majella et al. (3) determined that $18.3 \%$ of 569 pregnant women who were admitted to primary health care services in South India were high-risk pregnants and emphasized the importance of early diagnosis in the care and management of high-risk pregnancies. There are many risk factors in high risk pregnancies. Conditions that may pose a potential risk for high-risk pregnancy have been classified by The National Institutes of Health (Table 1) (4).

Risk perception during pregnancy affects the status of highrisk pregnant women seeking care and medical support. Risk perception is defined as "the person's expectation about the probability of an event happening". In a study conducted with nulliparous women, it was determined that pregnancy-related anxiety, medical risk conditions (reproductive history, medical condition, pregnancy complications), gestational age, the effect of the healthcare provider, previous experiences and one's life philosophy can affect the risk perception during pregnancy (5). Attention should be given to individuality in care, as the way the pregnant woman defines pregnancy-related risks may affect her ability to seek obstetric care and her willingness to maintain/ comply with the planned care plan. Risky situations perceived by the pregnant woman should be determined and the pregnant woman should be informed about the risks that she is not aware of (5).

This literature review was prepared in line with the literature in order to provide an up-to-date overview of the care of high-risk pregnancies. In the scope of the review, perinatal optimality was discussed in high-risk pregnancies in order to provide perinatal care without unnecessary interventions. The roles of the nurse and the models/theories that could be used in providing perinatal optimality were included. Patient safety, which was an important component of perinatal care, home care of high risk pregnant women and mobile applications that could be used in care were mentioned. In addition, consultancy and health education for improving maternal and fetal health in high risk pregnancies were discussed.

\section{Perinatal Optimality}

It is necessary to provide optimal care in order to continue the process in a healthy way both during high-risk pregnancy and healthy pregnancies. Optimal care in high-risk pregnancies focuses on obtaining and developing optimal results for the pregnancy and postpartum process for the pregnant, fetus, and the family. Optimality approach aims to provide individual care services in the complex pregnancy process, unlike routine obstetric interventions. One of the main conditions for ensuring optimality in this care process is to benefit from evidence-based approaches. Evidence-based individual-centered care provides safe and effective practices, improving the quality of perinatal care given to high-risk pregnant women and fetuses, and standardizing the care provided (3).

High-risk pregnancies may require lifestyle changes, medical support, technical support, and even hospitalization. Depending on the seriousness of the pregnant woman's health condition, a hospital stay may be necessary, starting weeks or months before the birth of the baby in high-risk pregnancies. Long-term hospitalization causes physical changes in the pregnant woman such as muscle atrophy, cardiovascular problems and bone loss (6). Pregnant women hospitalized in the antepartum period may experience psychological problems such as shock, depression, anxiety, sleep disorders, boredom, fear for the fetus and their own health, guilt, feeling trapped, loss of control, weakness, loneliness, anger and anxiety. The hospitalized pregnant can often experience anxiety for weeks or months with fear of the unknown. In the literature, it has been stated that pregnant women have more anxiety in high risk situations such as preterm birth risk, gestational diabetes and hypertension compared to normal pregnancy period. In addition, headache, constipation, hemorrhoids, gastrointestinal disorders, edema, back and lower abdominal pain that can be seen during pregnancy can be aggravated by hospitalization (3). High-risk pregnancy can also cause sleep problems, which are common during pregnancy, to emerge more prominently. One of the biggest problems experienced by high-risk pregnant women hospitalized is poor sleep quality. Poor sleep and short sleep time increase the risk of preterm birth and cesarean delivery. When the high-risk pregnant woman is hospitalized, her sleep becomes even more problematic as she experiences anxiety and stress for the fetus or her own health. Due to an uncomfortable bed, excessive light and sound exposure at night, and the foreign hospital environment, the sleep of the pregnant woman is frequently interrupted (6). In the study conducted by Lee and Gay (7) to improve the sleep quality of high-risk pregnant women in antepartum period in line with the BETTER model, it was determined that the sleep time and sleep quality scores of pregnant women increased in line with

Table 1. Classification of potential risk factors for high risk pregnancy

Current health conditions

\section{Age}

Lifestyle factors

Pregnancy conditions
Hypertensive disorders, polycystic ovary syndrome, diabetes, kidney disease, autoimmune diseases, thyroid disease, infertility, obesity, HIV/AIDS

Adolescent pregnancies, first pregnancy after the age of 35

Use of alcohol, tobacco and illegal drugs

Multiple pregnancy, gestational diabetes, preeclampsia and eclampsia 
the program implemented. The content of the sleep program developed in the study is given in Table 2. No other study utilizing the BETTER model in the care of high-risk pregnancies has been found in the literature. Accordingly, it may be suggested to perform new studies using the BETTER model to increase evidence-based studies in the care of high-risk pregnancies.

\section{The Roles of the Nurse in Providing Optimal Care}

Although the care of high-risk pregnant women requires a multidisciplinary approach, the responsibility of nurses in care is quite high. For this reason, nurses play a leading role in defining the problems and offering necessary solutions from the moment the high-risk pregnant woman encounters the healthcare team (8). Nurses in the multidisciplinary team have practiced on determining the real and possible risks in high risk pregnancies, making the necessary planning for care, supporting the implementation of care and treatment, and requesting consultation when necessary. Nurses have an important role in ensuring effective communication between the patient and the healthcare team and providing optimal care, since they are professionals within the health care team that the patient can easily reach. In addition, nurses should know the physiological care needs of high-risk pregnancy and aim to provide optimal care, and be sensitive about providing psychosocial support to the pregnant woman and her family. They should follow the technological applications that can be used in the optimal care and treatment of high-risk pregnancies, and inform the patient and her family about high-risk situations. Nurses should take responsibility for the administration of appropriate doses of drugs in the optimal care of high-risk pregnant women, and have information about their indications and side effects (9).
Concerns about the health of the pregnant woman can expose complex feelings about pregnancy and increase the level of anxiety. Proper and appropriate care provided by healthcare professionals positively affects the pregnancy and hospital stay experience. Interventions, especially to provide psychosocial support, of the nurses, who have the most interaction with highrisk pregnant women in the hospital compared to other health professionals, will have a key role in the care. Celebrations can be held at the hospital on days such as the $28^{\text {th }}$ or $32^{\text {nd }}$ week of pregnancy. A special meal for the pregnant woman and her family can be planned so that they can spend time together. Varied/flexible visiting hours, support and group therapies can be beneficial to reduce feelings of isolation and depression. In order to reduce the boredom of the pregnant woman, she should be encouraged to plan activities such as waking up at the same time of the day, eating, reading a book or magazine, listening to music and exercising. In order for the pregnant woman to feel better during the day, she should be supported in wearing different clothes and caring for her hair instead of standing in pajamas all day. Since the feeling of staying in a foreign environment will increase the stress of the pregnant woman, she should be allowed to bring her familiar and loved things from her home to the hospital. Counseling should be given in a multidisciplinary approach to help the pregnant woman express her fears and provide psychological support (10). Nurses also take part in pharmacological treatments as well as providing psychological support to the pregnant woman hospitalized. Hypnotic agents, which are frequently prescribed for hospitalized high risk pregnant women, are not recommended for pregnant women due to their adverse effects on the fetus. If these agents are used in treatment, attention should be paid. Nurses should also perform their treatments with this awareness (3). Nurses should know that

\section{Table 2. BETTER sleep program in hospitalized pregnant women with high-risk pregnancy}

Light, noise and temperature in the room affect the pregnant woman's sleep. Try eye masks and earplugs for better sleep. White noise is very effective in blocking the corridor noise. If you have a private bathroom in

Hospital room

Exercise

Stress

Time to try to sleep

Eating and drinking

Rhythm the room, there might be a fan you can leave at night for a white sound source. Ask your nurse for a battery powered fan or sound machine. The fan also keeps you cool and helps relieve nausea. The sound machine should be at the lowest possible volume. Try the "wind" setting first, avoid water sounds (ocean, thunderstorm, rain) if you have frequent urination.

Some daily activities are important for a good night's sleep. Ask your healthcare provider what physical activity is allowed. If you are at bed rest, you can consult your physical therapist about exercises you can do while in bed.

Ease your stress with relaxing activities in the evening to help you fall asleep. The relaxing activity can be reading a novel or solving a puzzle. Ask your nurse for reading material or a crossword book. Imagine lying on a sandy beach-feel the sun, rest your head on a beach towel, feel the hot sand on your legs and toes, listen to the waves. You can have a relaxation app you can try on your mobile phone or use the soothing options on your sound machine.

You should give yourself the opportunity to sleep at least eight hours a night. Ask your nurse or doctor to put the "do not disturb" sign on the door of your room.

A light protein snack or warm milk can help you relax and sleep better. Have light foods like crackers, peanut butter, and yogurt at the bedside. Avoid using caffeine (chocolate, cola, coffee, tea) at night. Decaffeinated herbal tea can make it easier for you to fall asleep thanks to its soothing effect.

A consistent schedule for day/light and night/dark is essential for your brain's sleep chemistry and better sleep. Take some light from your window during the day. Avoid exposure to light at night. Ask your nurse to cover the monitors with a pad. Go to bed at the same times every day to sleep and wear your eye mask. Send signals to your brain that it's time to sleep, turn off your television, cell phone, and other unnecessary light sources when you're ready to go to sleep. 
complementary therapies and behavioral approaches can be used in addition to pharmacological treatment in the treatment of high-risk pregnant women, and they should lead these practices to participate in the care process in cooperation with other health professionals (10). In the literature, Schlegel et al. (11) examined the effects of acupuncture, heat application and massage on pain and anxiety in hospitalized high-risk pregnant women, and it was found that the pain score was decreased from $84.5 \%$ to $61.4 \%$ and anxiety decreased by $70.9 \%$.

\section{Models/Theories That can be used in Optimal Care}

Models/theories can be used in the care and management of highrisk pregnancy, which is a complex process. The most important purpose of using a model/theory is to obtain a harmonious whole from parts by establishing a relationship between concepts. Each conceptual model/theory reflects a different perspective on the nursing discipline and offers the researcher a different roadmap, framework and methodological rules (10). Models/theories used in the care and management of many diseases can be useful in strengthening the self-care of pregnant women in high-risk pregnancies, increasing maternal sensitivity, providing comfort, eliminating sexual problems, increasing maternal satisfaction, adaptation of the mother to the hospital and pain management. Orem's Self-Care Deficit Theory, Roy Adaptation Model, Rogers/Unitary Human Theory, Comfort Theory, Functional Health Patterns Model, PLISSIT Model and Pender's Health Promotion Theory are among the models/theories that can be used in the care and management of high risk pregnancies (12). Orem's Self-Care Deficit Theory includes helping the individual in situations where she/he has difficulty in meeting her/his own care needs. Orem's Self-Care Deficit Theory can be used in providing/maintaining self-care of high-risk pregnant women who need to stay in a hospital or are on bed rest at home (13). The purpose of the Roy Adaptation Model is to help the individual to behave in harmony during the health and illness processes. It may be useful in helping high-risk pregnant women to adapt to the process physiologically and psychologically (14). According to Rogers/Unitary Human Theory, the interaction in the field of environment and human is continuous, reciprocal, simultaneous and spontaneous. This theory can be used to adapt high-risk pregnant women who are hospitalized (15). The Comfort Theory expresses relief, relaxation and the ability of the individuals to overcome their problems, depending on the type of individual needs that are not met. This theory can be used to provide and maintain the comfort of pregnant women in highrisk pregnancies (16). The Functional Health Patterns Model is used to collect data from the patient about the disease and to organize the obtained information. The Functional Health Patterns Model can be used in the early diagnosis and treatment of high-risk pregnancies, in the management of the treatment process, and in the follow-up of pregnant women for whom home visits are planned (17). Sexual counseling provided by the PLISSIT Model enables high-risk pregnant women to cooperate with health professionals. The model based on understanding and respecting the beliefs, value judgments and decisions of the patient can be used to help the sexual problems of high-risk pregnancies (18). Pender's Health Promotion Theory aims to improve the health of the individual, to increase his/her control over improving his/her own health. In high-risk pregnancies, this theory can be used to include pregnant women in care and treatment and to maintain the acquired healthy lifestyle behaviors (19). In the literature, there is no finding about which model/ theory is more effective in the care of high-risk pregnancies. It has been reported that the use of a model/theory for the needs of high-risk pregnant women is appropriate (17-19).

\section{Patient Safety Practices}

Patient safety is an important issue of quality in healthcare services and is one of the important indicators of providing qualified service. The purpose of patient safety is to prevent the harm caused by health care services to individuals and to create a suitable physical and psychological environment for patients, relatives and healthcare professionals by ensuring that employees take the necessary precautions (20). Hospitalized individuals experience problems about patient safety arising from identity errors, communication problems, errors arising from patient delivery and failure to comply with safe surgical steps, errors related to drug safety, falls, healthcare-related infections, errors caused by inappropriate and misuse of medical devices, errors due to patient transfer and medical errors. When high-risk pregnant women who have to stay in the hospital are exposed to other complications, especially problems caused by falls, both their and their babies' lives are threatened (21). In the literature, it is reported that if falls are not prevented, health care costs will increase due to complications arising from falls. It is estimated that the cost of fall injuries will be 55 million dollars annually until 2020 (22). Today, it is stated that the most common cause of non-obstetric maternal deaths is trauma during pregnancy, and the most common form of trauma is falling (25\%) (23). This rate was found to be $54.9 \%$ in a study conducted in our country (24). The reason for hospitalization of approximately $24 \%$ of pregnant women due to injury during pregnancy is falls (25). In a study evaluating postural balance and falls during pregnancy, an increase was observed in falls due to impaired posture, especially in the third trimester (26). In a study conducted with working pregnant women, it was determined that $26.6 \%$ of 2847 pregnant women fell at least once during their pregnancy and $6.3 \%$ of these falls occurred in the workplace. Walking on slippery ground, carrying heavy objects, and being in a hurry were shown to be among the main causes of falls (27). These results reveal how common falls are a problem in pregnant women and the importance of patient safety in hospitalized high-risk pregnancies.

The Joint Commission International prepared a report for all healthcare professionals, including nurses, to reduce falls and ensure patient safety (22). It was stated in the report that every individual hospitalized in the hospital should be evaluated in terms of fall risk and individuals in the high risk group should be followed up more closely. In the report, it was emphasized that nurses should be sensitive to determine the risky group by filling the fall risk assessment scale developed for pregnant women in pregnancy outpatient clinics, maternal and child health centers, emergency or services where high-risk pregnant women were 
hospitalized. A four-leaf clover symbol should be hung at the entrance of the room of pregnant women with high risk of falling. Hospitalized pregnant women should be informed about the use of the bed and about the location and use of the bathroom and call bell. When a pregnant woman wants to move or stand up, she should be informed about not getting up alone and asking for help from her nurse, and help with needs such as hygiene and toilet (28). In addition to these, nurses have responsibilities such as determining the history of falls, the risky drugs used, the balance status during pregnancy and the physical problems, raising awareness of the pregnant woman and her family about the risks of falling, and evaluating the data about falls. It is very important to determine the falling risks of high-risk pregnant women and to plan and implement appropriate interventions for these risks. Even if falls cannot be completely prevented, these scales should be used when diagnosing pregnant women, as falls can be reduced with effective protective measures and effective fall risk assessment scales (28).

\section{Home Care and Mobile Applications}

Providing health care in a natural environment at home allows the individual to feel more decisive in her/his life and at the same time to receive safer health care. Recent developments in information provision and communication technology have been used to increase the quality and speed of service delivery (29). Cockcroft et al. (30) examined the effects of home visits on maternal and infant health in 300 high risk pregnant women in a randomized controlled experimental study in Nigeria, which had the highest maternal mortality rates in the world. Three home visits were made during pregnancy and educational videos were used during the visits. As a result of the study, it was determined that in the group where home visits were organized, pregnancy and birth complications were less, benefiting from health services in one year after birth was more, and born children were healthier. In addition, higher level of knowledge, more use of health services, higher level of knowledge about pregnancy danger signs and higher rates of receiving home care were found in the group with home visits. It was determined that home trainings reduced the risk of preterm birth and facilitated learning about healthy lifestyle behaviors. In addition, home care reduced the duration and cost of hospital stay. In another study, it was determined that pregnant women who received home care in addition to routine prenatal care had fewer complications such as spontaneous premature rupture of membranes, preterm birth and hypertension compared to patients treated only in hospital. In addition to this, it was stated in the study that in home care services, healthcare providers would enable them to provide care in an environment where they could feel more comfortable and meet other family members. However, it was stated that today, the increasing workloads of healthcare professionals and developing new technologies emphasized the use of mobile health applications instead of constant home visits in home care of high-risk pregnancies (30).

World Health Organization defines mobile health (mHealth) as "Supporting public health and medical applications with personal digital devices, monitors, mobile phones and other mobile devices with wireless internet access" (31). Mobile health applications are used in many areas such as training of healthcare personnel and patients, follow-up of patients in the diagnosis and treatment process, protection and improvement of health, and storage of health data (32). In recent years, the increasing use of mobile phones and other technological tools and applications suggests that mobile health will be a force in improving maternal health services. During the prenatal period, the period in which mobile health applications are most frequently used is the pregnancy period. Mobile health applications are used to monitor and evaluate the health status of pregnant women and fetuses, to monitor high-risk situations occurring during pregnancy, to inform pregnant women about the pregnancy process and to gain healthy lifestyle behaviors (33). Tele ultrasound, Fetal Heart Rate Monitoring System/Mobile Integrated Doppler Device, The Pregnancy and Newborn Diagnostic Assessment (PANDA), Prenacell, telemedicine and telecare are among the most used mobile applications in the care of high risk pregnancies.

\section{Tele Ultrasound}

It is an up-to-date service useful in determining and preventing risk in high risk pregnancies. Examination with ultrasound in prenatal care has an important place in terms of fetus health and it maintains its importance from past to present. As a result of the ultrasound examination, an abnormality can be determined in the fetus, and findings regarding the continuation of the pregnancy can be revealed in genetic tests. However, access to ultrasound may not always be possible for all pregnant women. Pregnant women may have difficulties in accessing healthcare services, especially in rural areas due to transportation problems. Tele-ultrasound, which is one of the technological applications of today, enables a specialist doctor to evaluate the ultrasound from another location, especially in rural settlements and regions with insufficient resources (33).

\section{Fetal Heart Rate Monitoring System/Mobile Integrated Doppler Device}

The use of Non-stress Test (NST) devices is limited to the hospital environment. But today, it is possible to transfer instant data of the well-being of the fetus to the hospital database from mobile phone outside the hospital environment with the mDoppler device, without going to the hospital. The mDoppler device can be used from the $25^{\text {th }}$ week, just like the NST devices used routinely (34).

\section{The Pregnancy and Newborn Diagnostic Assessment (PANDA)}

One of the applications that can be used in antenatal care of high risk pregnancies is PANDA, a mobile health application that evaluates pregnant women and newborns. This mobile application consists of four modules: Personal information, medical history, follow-up, health education and birth plan. Medical supplies such as thermometer, measuring tape, sphygmomanometer, urine kit, glucometer, stethoscope, rapid tests for screening HIV and syphilis, and gloves are included in the care bag (35). 


\section{Prenacell}

In primary health care services, it is difficult for health service providers to include practices that improve health care services due to the workload. It has been reported in the literature that mobile applications such as SMS will be useful in the protection and improvement of health, in antenatal pregnancy followup and care. Prenacell is a mobile application designed to distribute content related to antenatal care, pregnancy and baby development via SMS. These SMS messages include antenatal care, pregnancy and delivery physiology, postpartum care and contraception, and psychological support during pregnancy and postpartum period (36).

\section{Tele Medicine and Tele Care}

Tele medicine is a technology that aims to improve the quality of patient care, increase access to medical care for rural and difficultto-transport areas, and reduce patient transfer and treatment costs. Tele care is considered as a subcategory for tele medicine. In the field of perinatology, the purpose of using tele care is to identify problems in the early stages, to provide treatment recommendations to prevent further complications and preterm births, to improve the outcomes of high-risk pregnancies, to reduce the number of newborns hospitalized in the neonatal intensive care unit and to reduce the number of hospital visits. For example, the tele care short message service (SMS-based) can be used to care for diabetic pregnant women and better access to maternal and neonatal health services. In a study aiming to reveal the results regarding the care of high-risk pregnant women living in rural areas of Tanzania through home visits, it was found that the rate of receiving two or more cares from healthcare workers and giving birth in hospital was higher in the group that received care and support through messages sent to their smart phones (37).

\section{Contribution of Mobile Applications to the Care of High Risk Pregnancies}

Taking advantage of mobile health applications enables pregnant women to participate in their own health care practices and to ensure that the cost of care is effective. Benefiting from mobile health applications in the care of high-risk pregnancy, which is a complex and versatile process, facilitates the work of nurses who take an active role in every stage of care (38). Mobile applications in the field of nursing provide support in the care process of highrisk pregnancy by facilitating communication between healthcare professionals who cannot be found in the same place. It facilitates the monitoring and follow-up of high risk pregnant women who do not have a health unit nearby or who cannot reach the health unit for various reasons. Mobile health applications also ensure that the care and counseling services to be provided by nurses are standardized. In addition, with mobile applications, nurses can train their high-risk pregnant women, provide consultancy and provide a safe care with continuous communication (39).

\section{Counseling and Health Education for Improving Maternal and Fetal Health in High Risk Pregnancies}

The pregnancy process includes psychosocial, physiological, economic, educational and family structure changes that do not cause unwanted situations in most cases. Although the pregnancy process is a physiological event, the risks related to pregnancy continue until this period ends. Some women may have pregnancy complications and for this reason they have "high risk" compared to other pregnant women. For this reason, it is very important for pregnant women to pay attention to their own health and the health of their babies, even for pregnant women classified as "low risk" in order to detect the presence of pregnancy complications. If there is any risk during pregnancy, the risks should be detected early, necessary planning should be made and appropriate interventions should be taken. Risk management in high risk pregnancy should be a dynamic process, not a static process. Nurses have important responsibilities in determining the educational needs of high-risk pregnant women and providing education in this care process. Nurses should establish closer relationships with pregnant women in a multidisciplinary health team compared to other health professionals, and provide their care with a holistic and comprehensive approach (40). Nurses should guide and support high-risk pregnant women using plain and understandable language, and encourage highrisk pregnant women to ask questions during health education. In addition, a hospitable and safe communication environment should be provided in health education groups through in-depth focus group meetings (41).

In the care of high-risk pregnant women, an individualized systematic care should be planned, facilitating the adaptation of pregnant women to the hospital and coping strategies should be developed. The use of mobile applications in the care of highrisk pregnant women will increase the feelings of trust and privacy of pregnant women during the delivery process (42). Pregnant women who are planned to be hospitalized during pregnancy should be informed about the hospitalization, their concerns should be understood and solutions should be sought. This interaction will ensure that high-risk pregnant women establish a stronger bond with the healthcare team and feel safe for themselves and their babies. In addition, high-risk pregnant women included in the process will feel more self-confident with the awareness of taking responsibility. Therefore, in coping with high risk pregnancies, healthcare professionals should listen actively to pregnant women and include the pregnant woman and her family in the care process. High-risk pregnant women should be given as much information as possible about pregnancy, adequate nutrition, delivery, postpartum period, breastfeeding and neonatal care before delivery (43). Coping with the crisis caused by high-risk pregnancy, which is a complex and stressful process, is a very difficult situation for both the family and the pregnant woman. Nurses should learn about the coping mechanisms used by pregnant women and their families in the past, and they should aim to bring them new coping mechanisms. It should not be forgotten that in highrisk pregnancy, individualized care should be provided to the pregnant woman in hospital or at home.

\section{Conclusion}

Nurses, who take an active role in the health care team, have important roles in the care and management of high risk 
pregnancies. Today's developing and changing scientific and technological applications also affect nursing care. Nurses are involved in the protection of health in preventive health services, in the implementation of treatment in therapeutic services and in the rehabilitation process. Providing and maintaining optimal care and patient safety is essential in preventive healthcare services in high-risk pregnancies. In this context, nurses should facilitate the communication of team members in a multidisciplinary team and aim for the pregnant woman to receive care in a safe environment. The nurse should follow the current literature as a curative service, be aware of the effects of drugs and inform the pregnant woman and her family. New technological applications can be used in home care of high risk pregnancies. Nurses should know mobile applications that can be used in the diagnosis and treatment of high risk pregnancies, and should include them in care as much as possible. Home care of high-risk pregnant women can be included in rehabilitative practices. The nurse should develop, implement and evaluate a home care plan by including the pregnant woman and her family in care. The nurse should provide psychological support to the pregnant woman and help her find activities that will make her feel good.

Peer-review: Internally peer reviewed.

\section{Authorship Contributions}

Concept: B.Y., Ü.O., Design: B.Y., Ü.O., Analysis or Interpretation: B.Y., Ü.O., Literature Search: B.Y., Ü.O., Writing: B.Y., Ü.O.

Conflict of Interest: No conflict of interest was declared by the authors.

Financial Disclosure: The authors declared that this study received no financial support.

\section{References}

1. Holness N. High-risk pregnancy. Nursing Clinics 2018;53:241-51.

2. World Health Organization. 2018. Available from: Maternal mortality. Available from: URL: http://www. who.int/mediacentre/ factsheets/fs348/en/ (19.09.2019).

3. Majella MG, Sarveswaran G, Yuvaraj Krishnamoorthy KS, Arikrishnan K, Kumar SG. A longitudinal study on high risk pregnancy and its outcome among antenatal women attending rural primary health centre in Puducherry, South India. J Edu Health Promot 2019;8:12-9.

4. Eunice Kennedy Shriver National Institute of Child Health and Human Development. 2018. United States of America: National Institutes of Health.Available from: URL: https:// www.nichd. nih.gov/health/topics/high-risk/conditioninfo/pages/factors.aspx. (17.09.2019)

5. Lennon SL. Risk perception in pregnancy: A concept analysis. J Adv Nurs 2016;72:20-9.

6. Rubarth LB, Schoening AM, Cosimano A, Sandhurst H. Women's experience of hospitalized bed rest during high-risk pregnancy. J Obstet Gynecol Neonatal Nurs 2012;41:398-407.
7. Lee KA, Gay CL. Improving sleep for hospitalized antepartum patients: A non-randomized controlled pilot study. J Clin Sleep Med 2017;13:1445-53.

8. Errico D, Bicalho G, Oliveira D, Martins F. The work of nurses in high-risk prenatal care from the perspective of basic human needs. Rev Bras Fisioter 2018;71:1257-64.

9. Alves C, Castro M, Souza R, Lira S, Sampaio R, Pereira P. Group of high-risk pregnant women as a health education strategy. Rev Lat Am Enfermagem 2019;40:1-8.

10. Dagklis T, Tsakiridis I, Chouliara F, Mamopoulos A, Rousso $\mathrm{D}$, Athanasiadis A, et al. Antenatal depression among women hospitalized due to threatened preterm labor in a high-risk pregnancy unit in Greece. J Matern Fetal Neonatal Med 2018;31:919-25.

11. Schlegel ML, Whalen JL, Williamsen PM. Integrative therapies for women with a high risk pregnancy during antepartum hospitalization. MCN Am J Matern Child Nurs 2016;41:356-62.

12. Okuyan Y, Tuna N, Can, HÖ. Theory and model based theses in midwifery practice areas. Life Sci 2018;14:20-9.

13. Rezaeean SM, Abedian Z, Latifnejad Roudsar R, Mazloom SR, Dadgar S. Application of Orem's theory for promotion of self-care behaviors of pregnant women at risk for preterm delivery: A clinical trial. IJOGI 2017;20:68-77.

14. Isbir GG, Mete S. Experiences with nausea and vomiting during pregnancy in Turkish women based on roy adaptation model: A content analysis. Asian Nurs Res 2013;7:175-81.

15. Reis PJ, Alligood MR. Prenatal yoga in late pregnancy and optimism, power, and well-being. Nursing Sci Q 2014;27:30-6.

16. Ünsan A. Hemşireliğin dört temel kavramı: İnsan, çevre, sağlık, hastalık, hemşirelik. Ahi Evran Sağlık Bilimleri Dergisi 2017;1:1125.

17. Erbaş N, Demirel G. Kadın sağlığının değerlendirilmesinde bir model: Fonksiyonel sağlık örüntüleri. Gümüşhane Üniversitesi Sağlık Bilimleri Dergisi 2016;5:84-91.

18. Uslu E, İnfal S, Ulusoy MN. Cinsel sorunların çözümünde Plissit modelinin etkisi. Psikiyatride Güncel Yaklaşımlar 2016;8:52-63.

19. Shin Y, Jang H, Pender NJ. Psychometric evaluation of the exercise self-efficacy scale among Korean adults with chronic diseases. Res Nurs Health 2001;24:68-76.

20. Korkmaz AÇ. Geçmişten günümüze hasta güvenliği. İnönü Üniversitesi Sağlık Hizmetleri Meslek Yüksek Okulu Dergisi 2018;6:10-9.

21. Bilgiç D, Şahin NH. Obstetride hasta güvenliği ve hemşirenin rolü. Turkiye Klinikleri 2018;4:118-30.

22. The Joint Commission International. National Patient Safety Goals Effective January 2019. Nursing Care Center Accreditation Program, 2019.p.1-9.

23. El Kady D. Perinatal outcomes of traumatic injuries during pregnancy. Clin Obstet Gynecol 2007;50:582-91.

24. Üstünyurt E, Akaltun C. Gebelikte minör travma: 173 olgunun değerlendirilmesi. J Clin Anal Med 2015;6:349-52.

25. Kuo C, Jamieson DJ, McPheeters ML, Meikle SF, Posner SF. Injury hospitalizations of pregnant women in the United States, 2002. Am J Obstet Gynecol 2007;196:161-6. 
26. Inanir A, Cakmak B, Hisim Y, Demirturk F. Evaluation of postural equilibrium and fall risk during pregnancy. Gait Posture 2014;39:1122-5.

27. Dunning K, LeMasters G, Levin L, Bhattacharya A, Alterman T, Lordo K. Falls in workers during pregnancy: Risk factors, job hazards, and high risk occupations. Am J Ind Med 2003;44:664-72.

28. Oksel E. Düşmeye hemşire bakışı ve değerlendirilmesi. Ege Tıp Bilimleri Dergisi 2018;1:140-2.

29. Cockcroft A, Omer K, Gidado Y, Gamawa AI, Andersson, N. Impact of universal home visits on maternal and infant outcomes in Bauchi state, Nigeria: protocol of a cluster randomized controlled trial. BMC Health Serv Res 2018;18:510-21.

30. Rastegari Z, Yarmohammadian MH, Mohammadi F, Kohan S. A comprehensive home-care program for health promotion of mothers with preeclampsia: Protocol for a mixed method study. Reprod Health 2019;16:32-8.

31. Kay M, Santos J, Takane M. mHealth: New horizons for health through mobile technologies. World Health Organization, 2011.p.66-71.

32. Overdijkink SB, Velu AV, Rosman AN, Van Beukering MD, Kok M, Steegers-Theunissen RP. The usability and effectiveness of mobile health technology-based lifestyle and medical intervention Apps supporting health care during pregnancy: Systematic review. JMIR Mhealth Uhealth 2018;6:e109.

33. Nader Z, Sandlin AT, Kevin A, Barber M, Wendy N, Magann EF. Tele ultrasound how accurate are we?. J Ultrasound Med 2017;36:232935.

34. Yüksel MU. Fetal kalp hızı monitörizasyon sistemi (FKHMS) ve mobil entegre doppler (M-DOPPLER) (Yüksek Lisans Tezi). İstanbul: İstanbul Aydın Üniversitesi Fen Bilimleri Enstitüsü, 2017.

35. Borsari L, Stancanelli G, Guarenti L, Grandi T, Leotta S, Barcellini L, et al. An innovative mobile health system to improve and standardize antenatal care among underserved communities: A feasibility study in an Italian hosting center for asylum seekers. J Immigr Minor Health 2018;20:1128-36.

36. Ciabati L, Alves D, Barbosa-Junior F, Vieira EM, Souza JP. SISPRENACEL-mHealth tool to empower PRENACEL strategy. Procedia Comput Sci 2017;21:748-55.

37. Hackett K, Lafleur C, Nyella P, Ginsburg O, Lou W, Sellen D. Impact of smartphone-assisted prenatal home visits on women's use of facility delivery: Results from a cluster-randomized trial in rural Tanzania. PloS One 2018;13:e0199400.

38. Ngabo F, Nguimfack J, Nwaigwe F, Mugeni, C, Muhoza D, Wilson $\mathrm{DR}$, et al. Designing and implementing an innovative SMS-based alert system (rapidSMS-MCH) to monitor pregnancy and reduce maternal and child deaths in Rwanda. Pan Afr Med J 2012;13:1-15.

39. Silva A, Mascarenhas A, Araújo M, Machado S, Santos D, Andrade R. Mobile technologies in the nursing area. Rev Bras Fisioter 2018;71:2570-8.

40. Chuang ST, Liu YF, Fu ZX, Liu KC, Chien SH, Lin CL, et al. Application of a smartphone nurse call system for nursing care. Telemed J E Health 2015;21:105-9.

41. Alves C, Castro EM, Souza R, Lira S, Sampaio R, Pereira P. Group of high-risk pregnant women as a health education strategy. Rev Lat Am Enfermagem 2019;40:1-7.

42. Pereira SB, Diaz G, Backes S, Ferreira L, Backes S. Good practices of labor and birth care from the perspective of health professionals. Rev Bras Enferm 2018;71:1313-9.

43. Gama SG, Viellas EF, Torres JA, Bastos MH, Brüggemann OM, Theme Filha MM, et al. Labor and birth care by nurse with midwifery skills in Brazil. Reprod Health 2016;13:123-32. 